http://economix.fr

International Financial Shocks in Emerging Markets

Document de Travail

Working Paper 2015-11
Michael Brei Almira Buzaushina

Université de Paris Ouest Nanterre La Défense (bâtiment G)

200, Avenue de la République 92001 NANTERRE CEDEX université

Paris Ouest 


\title{
International Financial Shocks in Emerging Markets*
}

\author{
Michael Brei $^{\dagger} \quad$ Almira Buzaushina ${ }^{\ddagger}$
}

April 13, 2015

\begin{abstract}
The present paper investigates how an emerging market economy is affected when it suddenly faces a higher risk premium on international capital markets. We study this question empirically for five Latin American economies over the period 1994-2007 within a structural panel vector autoregression and analyze theoretically the transmission mechanism using a dynamic stochastic general equilibrium model (DSGE) of a small open economy. The financial shock is modeled by an unexpected increase in the risk premium of firms' foreign-currency debt. In response, the adverse shock is amplified by a feedback mechanism between currency depreciation, adverse balance sheet and risk premium effects. The theoretical model is used to study different monetary policy responses. We find that an exchange rate targeting rule that strikes a balance between exchange rate and inflation targeting allows the monetary authority to stabilize inflation and output more effectively than under a pure inflation targeting rule.
\end{abstract}

Keywords: Emerging Markets, Financial Crises, International Capital Markets

JEL Classification: F34, F36, G21

\footnotetext{
${ }^{*}$ We would like to thank Jean-Pierre Allegret, Anthony Birchwood, Patrice Borda, Jörg Breitung, Matthieu Charpe, Zeno Enders, Michael Evers, Michel Juillard, Alain Maurin, Gernot Müller, Alfredo Schclarek, Martín Uribe, Jürgen von Hagen, Tovonony Razafindrabe and Carlos Winograd for helpful comments. An earlier version of this paper circulated under the title "Matching International Financial Shocks in Emerging Markets". The views expressed in this paper do not necessarily reflect the views or policy of the IMF or the Deutsche Bundesbank.

${ }^{\dagger}$ EconomiX-CNRS, Université Paris Ouest Nanterre La Défense and SALISES, The University of the West Indies, michael.brei@uni-bonn.de

${ }^{\ddagger}$ International Monetary Fund and Deutsche Bundesbank, abuzaushina@imf.org
} 


\section{Introduction}

Over the last two decades a number of emerging market economies have experienced serious economic and financial crises. Some of these crises appear to have been triggered by financial turmoil on international capital markets. This is evidenced by the fact that the financial distress affected a broader range of emerging market economies at the same time. Figure 1 shows the country risk premium of seven Latin American economies. ${ }^{1}$ Remarkably the country spreads appear to be highly correlated, particularly so during the region's major crisis periods of 1994-95, 1998 and 2001-02.

The turbulent times in the region seem to have gone by in more recent years. The country spreads have decreased significantly just as much as their implied volatility, resulting, as has been argued, from improvements in macroeconomic and prudential policies and a number of structural reforms (De Gregorio, 2013). As a consequence, the global financial crisis of 2008-09 that originated in the advanced economies had a rather moderate and temporary impact on Latin America (Batten and Szilagyi, 2011).

Figure 1: Country risks in Latin America
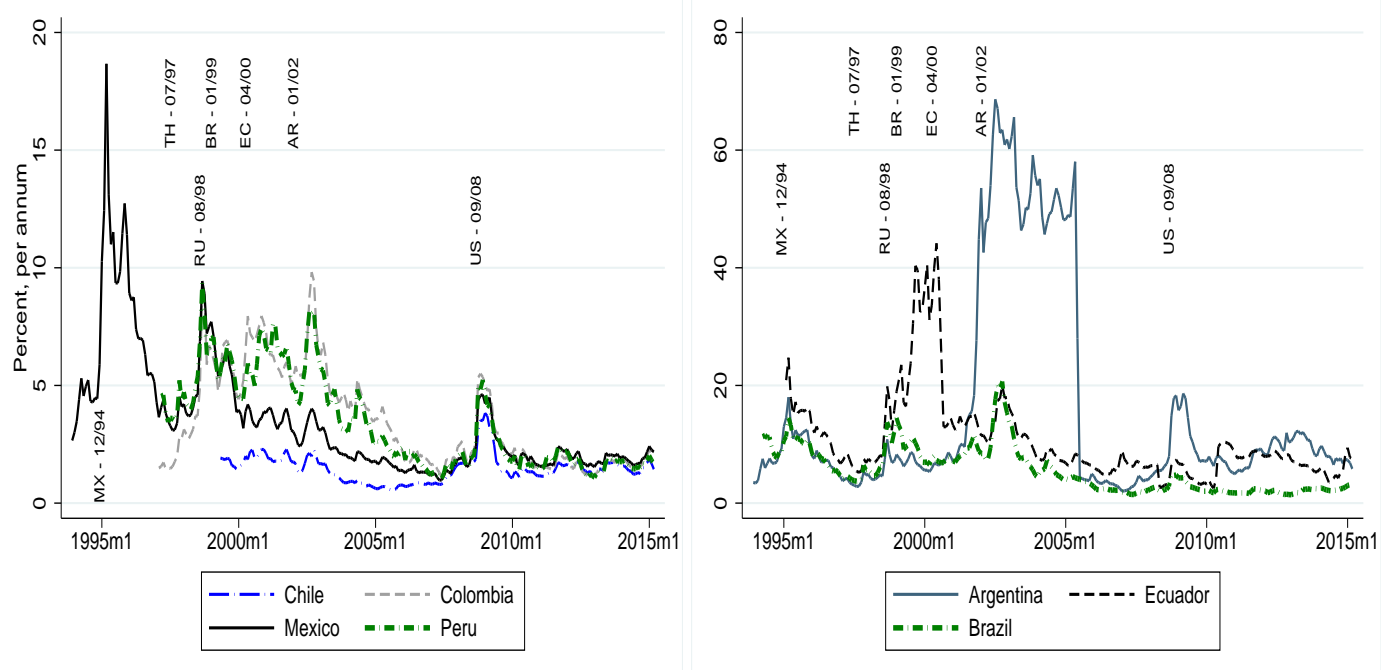

The observation that country risks have been adversely affected across borders motivates us to model the financial turmoil in these countries by an initially exogenous shock to country spreads. However, as can been seen in Figure 1, the amplitude of the financial propagation varied significantly across countries, indicating that domestic factors are crucial in the transmission and amplification of the financial turbulence.

As has been pointed out by Calvo et al. (2006), the external shocks can be followed by a painful adjustment or become a minor recession. It appears that particular weaknesses such as currency mismatches on firms' and banks' balance sheets or excessive external borrowing have been at the center of many emerging market crises (Hausmann et al., 2001; Calvo and Reinhart, 2002; Roubini

\footnotetext{
${ }^{1}$ Country risk is measured by the spread of JP Morgan's Emerging Markets Bond Index Plus (EMBI+) over 10-year US government bonds. The vertical text in Figure 1 indicates the onset of the following crises: Mexico (MX), Thailand (TH), Russia (RU), Brazil (BR), Ecuador (EC), Argentina (AR) and United States (US). Dates are indicated, for example, 12/94 reads as December 1994.
} 
and Setser, 2004; Brei and Charpe, 2012). In countries where macroeconomic fundamentals have been solid, as in Chile, the financial amplification of the international shocks has been much less important (Calvo and Talvi, 2005).

The theoretical literature incorporates such amplification mechanisms through credit market frictions in the form of collateral constraints on borrowing or financing costs that depend on borrowers' balance sheets (Bernanke and Gertler, 1989; Kiyotaki and Moore, 1997; Arellano and Mendoza, 2003; Christiano et al., 2004; Céspedes et al., 2004; Cook and Devereux, 2005; Mendoza, 2006; Uribe and Yue, 2006; Gertler et al., 2007; Braggion et al., 2009; García-Cicco et al., 2010; Mendoza, 2010). In many of these models, an initial adverse shock sets in motion a circle of amplification between worsening financial conditions, financial deleveraging, decreases in (asset) prices and deterioration in borrowers' creditworthiness. Prominent examples of this include the debt-deflation mechanism on the interaction of unexpected drops in output prices and borrowers' balance sheets (Fisher, 1933), the financial accelerator mechanism on the interaction of agency costs, macroeconomic fluctuations and borrowers' balance sheets (Bernanke and Gertler, 1989), or the balance sheet mechanism associated with the interaction of liability dollarization and unexpected currency depreciation (Céspedes et al., 2004). ${ }^{2}$

Against these backdrops, we investigate in this paper the impact of external financial shocks on the emerging market economies of Latin America. Our contribution to the existing literature is twofold. On the one hand, we estimate the impact of adverse shocks to country risk premia on the real economy using a structural panel vector autoregression of GDP, investments, trade balance, domestic credits and country spreads. The results suggest that increases in country risk premia have been followed by persistent drops in investments, credits and GDP in these countries, while the trade balance improved. On the other hand, we investigate the real effects of the financial distress and optimal monetary policy within a dynamic stochastic general equilibrium (DSGE) model of a small open economy (SOE).

To this end we develop and estimate - by impulse response matching - a DSGE model that reflects a number of structural characteristics of emerging markets. More specifically, we consider an economy that produces tradable and non-tradable goods using a combination of labor, capital and imported materials, acting as a price-taker on international goods markets. While labor and imported materials are financed by intratemporal working capital loans and trade credits, investments in the capital stock are financed with intertemporal debt issued on the international capital market in foreign currency and subject to a debt-elastic risk premium. Our assumption hereby is that international investors use the economy's external leverage expressed in domestic currency to infer its creditworthiness, based on the idea that a large level of foreign-currency debt can exacerbate debt service difficulties and wreck domestic balance sheets, when the exchange rate depreciates (Céspedes et al., 2004). As a consequence, an initially small shock in our model can be re-enforced by a vicious circle of worsening financial conditions, financial deleveraging, currency depreciation and increases in financing costs.

Our theoretical framework builds on the limited participation model of Christiano et al. (2004). There are, however, three important differences. First, we do not model the financial shock in the form of a binding borrowing constraint, but rather we incorporate the shock in the risk premium on external debt. Second, not only the household's deposit decision is made prior to the shock, as in classical limited participation models, but also the firm decides on production and financing in advance (Uribe and Yue, 2006). And third, we estimate a subset of structural parameters by matching theoretical with empirical impulse responses. The results suggest that the proposed model fits the observed dynamics

\footnotetext{
${ }^{2}$ More recently, theoretical models consider as well other types of financial shocks and transmission mechanisms, see amongst others Christiano et al. (2010); Gerali et al. (2010); Del Negro et al. (2011); Kollmann et al. (2011); Jermann and Quadrini (2012) and Gambacorta and Signoretti (2014).
} 
remarkably well. With regard to the optimal monetary policy response, we find that an interest rate rule that strikes a balance between exchange rate and inflation targeting allows the monetary authority to stabilize inflation and output more effectively compared to a pure inflation targeting rule.

The remainder of this paper is organized as follows. Section 2 presents the estimation results and the empirical impulse response functions. In Section 3 we discuss the theoretical model and present the numerical simulations of the estimated model. Section 4 evaluates the optimal monetary policy response and Section 5 investigates the role of external leverage in the financial amplification mechanism. The final section concludes.

\section{Shocks to the country risk premium in Latin America}

In this section we investigate how an emerging market economy is affected when it suddenly faces a sharp increase in the country risk premium on global capital markets. The econometric results serve as a benchmark against which our theoretical model will be compared and estimated. As highlighted in Figure 1, Latin American country spreads have been highly volatile, especially during the period 1994-2007. In more recent years, country spreads and the implied volatility went down as a result of both improvements in macroeconomic policies and structural reforms adopted during the last decade (De Gregorio, 2013). ${ }^{3}$

The period of turbulent times 1994-2007, studied in this paper, has been marked by a number of systemic crisis periods (Dornbusch et al., 2002; Calvo et al., 2006). For instance, while the Tequila crisis of 1994-95 has been followed by increases in the country spreads of Argentina (increase by 9\% p.a.) and Brazil (6\%), the LTCM crisis of 1998 associated with the Russian default has been succeeded by financial distress in Brazil (5\%), Colombia (5\%) and Ecuador (6\%). The Argentinean crisis of 2001-02 has most adversely affected Brazil (12\%), but increases in country spreads have also been felt in Colombia and Peru. The evidence presented so far highlights that the financial turmoil had different origins and impacts across countries. Most vulnerable to the financial contagion and amplification have been Argentina, Ecuador and Brazil, while Chile has been most resilient.

The real effects of the financial shocks are investigated with the use of empirical impulse response functions (IRFs) derived from a structural vector autoregression (S-VAR). Since we are interested in estimating the average response for Latin America, we use a panel setting which has several advantages compared to a study on the individual country level. First, a panel framework increases the efficiency and power of the regressions relative to country-specific estimates which might be prone to problems associated with low degrees of freedom, i.e., a high number of estimated parameters in relation to the number of observations (Goodhart and Hofmann, 2008). It has been argued that a potential drawback of any panel approach is the assumption of common parameters and dynamic responses across countries. While this criticism has to be taken seriously, it should be seen in relation to small sample problems prevalent in the context of emerging markets and the possibility of selecting a rather homogenous group of countries. In this context, a panel approach may actually help to uncover common dynamic relationships that might be obscured by idiosyncratic effects on the country level (Gavin and Theodorou, 2005).

Based on a number of sensitivity tests, we focus in this paper on the period 1994-2007 and five of the seven Latin American economies presented in Figure 1 (LA-5): Brazil, Colombia, Ecuador (pre-

\footnotetext{
${ }^{3}$ Several factors have been pointed out in making Latin American countries more resilient: low levels or absence of internal and external deficits, flexible exchange rates, well regulated financial systems and high levels of international reserves. Moreover, given that most Latin American countries are commodity exporters, they have benefited from increasing export revenues associated with favorable commodity prices observed during the second half of the 2000s.
} 
dollarization), Mexico and Peru. ${ }^{4}$ We decided to exclude Argentina, because over our sample period it has been structurally different due to the convertibility regime, in place prior to December 2001, and the subsequent sovereign default, floating and pesification which ultimately led to the closure of international capital markets for a number of years. ${ }^{5}$ We decided to exclude also Chile from our estimations, since it may be seen as another (positive) outlier due to its solid economic performance, political stability and better resilience to external shocks (Calvo and Talvi, 2005). ${ }^{6}$ And finally, we required that our sample of countries had at least some form of exchange rate flexibility to be consistent with our theoretical model, which led us to exclude Ecuador's period of dollarization. ${ }^{7}$

The vector autoregressive model consists of the country spread and four macroeconomic variables: GDP, investment, trade balance, and domestic credits, which have been identified in the emerging market literature as being highly related to country spreads (Tornell and Westermann, 2002; Uribe and Yue, 2006). Our basic identifying assumption is that the real variables respond to innovations in country risk premia with a lag, and that country risk premia react to innovations in the real variables instantaneously. This identification strategy reflects the view that decisions on production and investment take time to plan and implement, in contrast to financial markets that are able to react more quickly to news about the state of the business cycle. ${ }^{8}$ While these assumptions are to some extent debatable, it should be noted that the analysis is internally consistent in the sense that we make the same assumptions in our theoretical model. The ordering of variables other than the country spread does not affect our results on country risk shocks, since they are ordered last (see also (Christiano et al., 1999)).

\footnotetext{
${ }^{4}$ We decided to focus on the period 1994-2007, because the global financial crisis has induced a structural break implying that the coefficients of the VAR system cannot be treated as constant, if the crisis period is included. On the one hand, U.S. monetary policy - due to the binding zero lower bound and the resulting quantitative easing and tapering - affected emerging markets' capital flows. Some central banks were even forced to resort to uncommon policies (e.g., capital controls in Brazil). On the other hand, yields for emerging markets were significantly lower and (with a short exception in 2008) less volatile, see Figure 1. Hence, the time series seem to follow a different regime since approximately 2008 . We therefore believe that it is a more conservative strategy to restrict ourselves to the period prior to the financial crisis. However, we have also re-estimated our VAR model using data up to end-2014. The results are available upon request. While they are similar to the results obtained for 1994-2007, we note a decrease in the persistence of the economic adjustment in response to country risk shocks.

${ }^{5}$ The estimation results with Argentina are qualitatively similar but subject to higher estimation uncertainty, which is presumably due to the peculiar dynamics of the Argentinean country spread, see Figure 1.

${ }^{6}$ The estimation results with Chile are qualitatively and quantitatively similar and are available upon request.

${ }^{7}$ Mexico operates under a free floating regime since end-1994, while Brazil and Colombia adopted a pure floating and inflation targeting regime in 1999 and Peru in 2002 (Banco de Mexico, 2009; Frenkel and Rapetti, 2010). Prior to that, Brazil used a semi-fixed exchange rate regime with an asymmetric band, while Colombia and Peru operated under a managed floating regime. Ecuador used a crawling peg prior to its dollarization. The estimation results for the period 1994-2007 without Brazil prior to 1999 and Ecuador are similar but subject to somewhat higher estimation uncertainty. The estimation results for the period 1994-2014 for only floating exchange rate regimes are, however, similar.

${ }^{8}$ The assumption on a sluggish response of the real variables is standard in the literature on monetary policy shocks (Friedman, 1968; Christiano et al., 1999, 2005). Furthermore, the assumption on the instantaneous response of financial variables is common in the recent literature on financial market shocks (Lown and Morgan, 2004; Uribe and Yue, 2006; Goodhart and Hofmann, 2008; Gilchrist et al., 2009).
} 
Given our assumptions, the structural vector autoregressive model can be represented as follows:

$$
\begin{aligned}
& \mathbf{A}_{\mathbf{0}} x_{t}=\alpha+\alpha_{j}+\sum_{i=1}^{p} \mathbf{A}_{\mathbf{i}} x_{t-i}+\varepsilon_{t}, \\
& \mathbf{A}_{\mathbf{0}}=\left(\begin{array}{ccccc}
1 & 0 & 0 & 0 & 0 \\
a_{21} & 1 & 0 & 0 & 0 \\
a_{31} & a_{32} & 1 & 0 & 0 \\
a_{41} & a_{42} & a_{43} & 1 & 0 \\
a_{51} & a_{52} & a_{53} & a_{54} & 1
\end{array}\right), x_{t}=\left[\begin{array}{c}
y_{j t} \\
i_{j t} \\
t b_{j t} \\
c_{j t} \\
r_{j t}
\end{array}\right], \varepsilon_{t}=\left[\begin{array}{c}
\varepsilon_{j t}^{y} \\
\varepsilon_{j t}^{i} \\
\varepsilon_{j t}^{t b} \\
\varepsilon_{j t}^{c} \\
\varepsilon_{j t}^{r}
\end{array}\right],
\end{aligned}
$$

where $t$ refers to the time dimension, $j$ to countries, $p$ to the autoregressive lag length, $\alpha$ to the constant and $\alpha_{j}$ to country fixed effects. Moreover, $y_{j t}$ denotes real GDP, $i_{j t}$ real investment, $t b_{j t}$ the trade balance to GDP ratio, $c_{j t}$ real domestic credits and $r_{j t}$ the country spread. Note that GDP, investment and domestic credits are expressed in log-deviations from a log-linear trend. Summary statistics for the regression variables are provided in Table 1 . While our identification implies that the matrix $\mathbf{A}_{\mathbf{0}}$ is triangular, there are no restrictions on the other coefficient matrices $\mathbf{A}_{\mathbf{i}}, 1 \leq i \leq p$.

It is well known that the estimation of dynamic panel models with fixed effects by OLS is biased in samples with a small time dimension (Nickell, 1981). In order to overcome this drawback of the fixed effects OLS panel estimator, we estimate our model equation-by-equation with the system Generalized Method of Moments (GMM) estimator for dynamic panel data (Arellano and Bover, 1995) and use deeper lags of the lagged dependent variables as instruments. Moreover, given that the other macroeconomic variables that enter the system contemporaneously are likely to be endogenous, we instrument in addition these variables with deeper lags.

The estimation results are reported in Table 2. ${ }^{9}$ The specification tests indicate that there is no incidence of 2nd order autocorrelation in the error terms and that instruments are valid except for the GDP equation. The variables in the VAR system are positively autocorrelated and satisfy the stationarity conditions for autoregressive processes of order 2. Moreover, the estimated coefficients show the expected signs. Focusing on the short-term impact of increases in country risk premia, the results suggest that real GDP and investment decrease significantly after one quarter, while the trade balance improves. The largest impact of country spreads is observed for GDP, i.e., based on standardized coefficients we can infer that an increase in the country spread by one standard deviation results in a drop of GDP by -0.146 standard deviations. Real domestic credits are negatively affected, however, the coefficient is not statistically significant.

Based on the moving average representation, we calculate the impulse response functions to a country risk shock of $5 \%$ per quarter (22.5\% annually). The magnitude of the financial shock reflects a sharp and unusual increase in the countries' risk premium, and it can be seen as a tail risk with low but non-negligible probability (within the 95th percentile of the distribution). The resulting impulse response functions are shown in Figure 2. In response to the initial shock, the country spread increases and reverses steadily towards zero. The half-life of the response is approximately one year. The real economy is significantly affected in the following period and the financial shock results in a prolonged recession. The downturns in GDP and investments reach their peak after 3 quarters and domestic credits after 8 quarters. Real investments drop by $15 \%$ and real GDP by $5 \%$ from trend. The financial deleveraging is associated with an improvement in the trade balance by 4 percentage points of GDP. The shock to the country risk premium also affects the domestic banking sector and is followed by a

\footnotetext{
${ }^{9}$ Based on the Schwarz information criterion which is equal to $\{-34.69,-34.98,-34.68,-34.31\}$ for the lag lengths of $p=1,2,3,4$, we choose an $\operatorname{VAR}(2)$ model. The results obtained with the other lag structures are qualitatively similar.
} 
drop in domestic credits of $15 \%$ from trend. While the trade balance, domestic credits and country risk recover after about 5 years, the recovery of GDP and investment takes longer.

The empirical evidence suggests that sharp increases in the country risk of the Latin American economies have been followed by long-lasting downturns in economic activity and domestic lending. As has been pointed out in the literature, there seems to be a financial accelerator mechanism at work through which the real effects of worsening financial conditions are amplified by currency depreciation and adverse balance sheet effects (Hausmann et al., 2001; Calvo and Reinhart, 2002; Céspedes et al., 2004). From an ex-ante point of view, it is not evident how central banks should react to such shocks. The optimal reaction will ultimately depend on an economy's structural and financial characteristics, including the reaction of households, financial markets and the corporate sector. In the next section, we will address these issues and investigate the involved transmission mechanism and optimal monetary policy within an estimated DSGE model.

\section{The Theoretical Model}

In this section, we develop a theoretical model that reflects a number of structural characteristics of emerging markets. In our environment, unexpected financial shocks originating in international capital markets may occur and affect the real economy. To analyze the transmission mechanism of these shocks, we consider a small open economy (SOE) version of a cash-in-advance (CIA) model with limited participation augmented with a financial friction in the form of a debt-elastic risk premium on external funds. ${ }^{10}$ The SOE is inhabited by four types of agents including a representative household, firm, financial intermediary and a monetary authority.

\subsection{Households}

A representative household derives life-time utility from a composite consumption good $C_{t}$ and disutility from labor $L_{t}$ :

$$
\mathbf{U}=E_{t} \sum_{j=0}^{\infty} \beta^{j} U\left(C_{t+j}, L_{t+j}\right),
$$

where $\beta$ denotes the household's time preference parameter. The instantaneous utility function takes the form:

$$
U\left(C_{t}, L_{t}\right)=\frac{\left(C_{t}-\frac{L_{t}^{\mu}}{\mu} C_{t}^{\gamma}\right)^{1-\sigma}-1}{1-\sigma}, \mu>0, \sigma>0, \sigma \neq 1, \gamma \geq 0,
$$

where $\sigma$ denotes the intertemporal elasticity of substitution of consumption, $\mu$ the intertemporal elasticity of substitution of labor supply, and $E_{t}$ the expectations operator conditional on time $t$ information. Note that the preferences include as a special case, for $\gamma=0$, the preferences proposed by Greenwood et al. (1988) which rule out wealth effects on the labor supply. We incorporate this type of preferences to control for the strength of the wealth effect by choosing $\gamma$. The composite consumption good consists of a domestic tradable and a non-tradable good:

$$
C_{t}=\left(n^{\frac{1}{\lambda}} C_{T t}^{\frac{\lambda-1}{\lambda}}+(1-n)^{\frac{1}{\lambda}} C_{N t}^{\frac{\lambda-1}{\lambda}}\right)^{\frac{\lambda}{\lambda-1}}, 0<n<1, \lambda>0,
$$

where $n$ is the share of tradable goods in composite consumption and $\lambda$ is the constant elasticity of substitution between the consumption of tradable and non-tradable goods.

\footnotetext{
${ }^{10}$ For a detailed description of CIA models, see Christiano (1991), Christiano and Eichenbaum (1992), and Christiano et al. (1997).
} 
At the beginning of period $t$, the household carries over its cash from the previous period $M_{t-1}$, gets prepaid paychecks $W_{t} L_{t}$, and deposits a cash amount $D_{t}$ with the financial intermediary. The CIA constraint requires that all consumption expenditures must be paid with cash available at the beginning of period $t$ :

$$
P_{t} C_{t} \leq M_{t-1}-D_{t}+W_{t} L_{t}
$$

where $P_{t}$ denotes the price index for the composite consumption good given by:

$$
P_{t}=\left(n P_{T t}^{1-\lambda}+(1-n) P_{N t}^{1-\lambda}\right)^{\frac{1}{1-\lambda}} .
$$

Maximizing composite consumption subject to total expenditures with respect to the consumption of tradable and non-tradable goods, we obtain the demand functions for tradable and non-tradable goods:

$$
\begin{aligned}
C_{T t} & =n\left(\frac{P_{T t}}{P_{t}}\right)^{-\lambda} C_{t}, \\
C_{N t} & =(1-n)\left(\frac{P_{N t}}{P_{t}}\right)^{-\lambda} C_{t},
\end{aligned}
$$

where both are decreasing in the ratio of the good's price relative to the overall price index.

The budget constraint of the household, who owns the firm and bank, reflects the evolution of its assets: cash at the beginning of period $t+1$ is equal to the sum of net dividends that it receives from the firm $\left(\pi_{t}^{F}\right)$ and the financial intermediary $\left(\pi_{t}^{B}\right)$, interest earnings and repaid deposits loaned to the financial intermediary at the beginning of the period $\left(R_{D t} D_{t}\right)$, and any cash that is left from financing consumption expenditures:

$$
M_{t}=\pi_{t}^{F}+\pi_{t}^{B}+R_{D t} D_{t}+\left(M_{t-1}-D_{t}+W_{t} L_{t}-P_{t} C_{t}\right) .
$$

The household maximizes its life-time utility (2) subject to the CIA (4) and budget (5) constraints. A period's deposit decision is made before the financial shock occurs, while the decisions on consumption and labor supply are made afterwards.

The first-order condition associated with the employment decision implies that in the optimum the consumer chooses consumption and labor such that the marginal rate of substitution between consumption and leisure is equal to their relative price:

$$
\frac{U_{C_{t}}}{U_{L_{t}}}=-\frac{P_{t}}{W_{t}} .
$$

The intertemporal Euler equation associated with the deposit decision implies that the marginal utility of consumption, or equivalently marginal utility of leisure, is equal between two consecutive periods, conditional on time $t-1$ information due to the assumption of limited participation:

$$
E_{t-1} \beta \frac{U_{C_{t+1}}}{P_{t+1}}=E_{t-1} \frac{U_{C_{t}}}{R_{D t} P_{t}} .
$$

\subsection{Firms}

The international financial shock affects the economy through the corporate sector. The representative firm produces two types of goods, tradables and non-tradables, using labor $L_{t}$, capital $K_{t}$, and imported materials $I M_{t}$ as input factors. We assume that the firm has access to three types of credits. 
It borrows at the beginning of period $t$ domestic short-term credits, $B L_{t}$, from the financial intermediary to hire labor (bank loans), and foreign short-term credits, $S F_{t}$, on the global capital market to prepay imported materials (trade credits). The firm repays these loans including interest payments at the end of the period. In addition, we assume that the firm can borrow foreign long-term credits, $F L_{t}$, on the global capital market, which have to be repaid in the next period. These credits are used to finance investment. We assume that external debt is denominated in foreign currency, which is in line with the original sin theory (Eichengreen et al., 2005), and subject to a risk premium, which depends on the firm's level of debt. Opposed to Christiano et al. (2004), we assume that the firm decides on production at the beginning of period $t$, i.e., before the financial shock is realized, to capture that employment and investment decisions take time to plan. The timing in our model can be represented as follows:

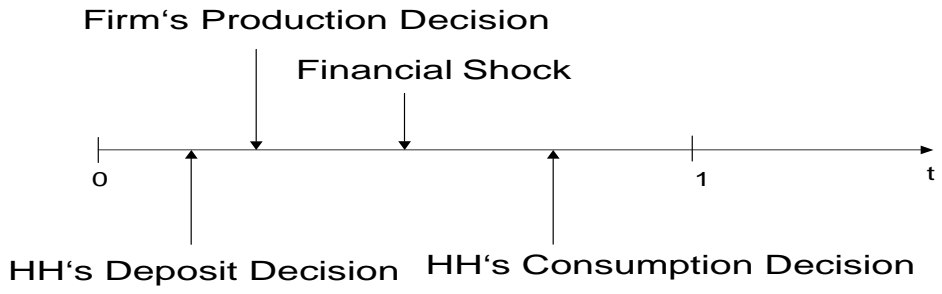

It implies that the consumer decides on deposits and the firm on production before the financial shock occurs. After the financial shock is realized in the middle of period $t$, the household makes its consumption decision, and prices adjust such that all markets clear. Note that these timing assumptions ensure the consistency between the theoretical and empirical model discussed in Section 2.

The production functions of tradable and non-tradable goods are given by:

$$
\begin{aligned}
Y_{T t} & =A_{T} K_{T t-1}^{\alpha_{T}}\left(I M_{t}^{\nu} L_{T t}^{1-\nu}\right)^{1-\alpha_{T}}, 0<\alpha_{T}<1,0<\nu<1, \\
Y_{N t} & =A_{N} K_{N t-1}^{\alpha_{N}} L_{N t}^{1-\alpha_{N}}, 0<\alpha_{N}<1,
\end{aligned}
$$

where $A_{T}$ and $A_{N}$ denote technology processes that are assumed to be constant. Note that $\alpha_{i}$ denotes the capital share in the production of each good and $\nu\left(1-\alpha_{T}\right)$ the import share in the production of tradable goods. The labor shares in the production of tradable and non-tradable goods are given by $(1-\nu)\left(1-\alpha_{T}\right)$ and $\left(1-\alpha_{N}\right)$, respectively. The firm accumulates two types of capital stocks, one for each sector:

$$
K_{i t}=I_{i t}+(1-\delta) K_{i t-1}, i=T, N,
$$

where $I_{i t}$ denotes investment in period $t$ and $0<\delta<1$ the rate of capital depreciation. We assume that changes in the stock of capital are subject to quadratic capital adjustment costs:

$$
A C\left(K_{i t}, K_{i t-1}\right)=\frac{\gamma_{i}}{2}\left(\frac{K_{i t}-(1-\delta) K_{i t-1}}{K_{i t-1}}\right)^{2} K_{i t-1}, i=T, N,
$$

with an adjustment cost parameter denoted by $\gamma_{i} \geq 0$.

The firm starts each period with no cash, because all profits from the previous period are distributed to the household. Implied by the assumption of advance payments of labor and imports, 
the firm borrows domestic bank loans $\left(B L_{t}\right)$ to hire labor, and foreign trade credits $\left(S F_{t}\right)$ to prepay imported materials. In particular, the working capital constraints faced by the firm are given by:

$$
\begin{aligned}
B L_{t} & \geq W_{t} L_{T t}+W_{t} L_{N t}, \\
S F_{t} & \geq p_{I M t}^{*} I M_{t},
\end{aligned}
$$

where $p_{I M t}^{*}$ denotes the price of imported materials expressed in foreign currency. Since domestic bank loans and foreign trade credits have to be repaid including interest payments at the end of each period, the effective costs of labor and imported materials in domestic currency are equal to $R_{B t} W_{t} L_{t}$ and $e_{t} R_{S t} p_{I M t}^{*} I M_{t}$, respectively. The nominal exchange rate $e_{t}$ is denoted as the domestic price per unit of foreign currency. $R_{B t}$ denotes the gross interest rate on domestic bank loans and $R_{S t}$ that of trade credits. We assume that $R_{S t}$ is equal to the risk-free interest rate on external long-term credits, $1+r$. The gross interest rate on foreign long-term credits $R_{F t}$ is composed of a constant risk-free component and a variable risk premium:

$$
R_{F t}=(1+r)+\kappa \exp \left(e_{t} F L_{t}-\bar{e} \overline{F L}\right)+R P_{t}, \kappa \geq 0 .
$$

In particular, it is assumed that the risk premium consists of a debt-related component, which increases when external long-term credits measured in domestic currency rise above their steady-state level, and a stochastic component, $R P_{t}$, which is intended to capture aggregate risks. The stochastic component is assumed to follow a stationary $\mathrm{AR}(1)$ process $R P_{t}=\rho_{R P} R P_{t-1}+\epsilon_{R P t}$.

Note that we do not derive this risk premium explicitly from a debt-contracting problem between borrowers and lenders, rather we use a reduced form and assume that lenders charge additional interests when the firm's level of external debt expressed in domestic currency increases relative to its long-run average. We use this specification, because it summarizes the dynamics of the risk premium in two key variables (exchange rate and level of foreign currency debt), which have been highlighted in the empirical literature to be important determinants of emerging market risk premiums (Berganza et al., 2004). We believe that our choice is justified in the context of a general equilibrium model, however, other specifications of the risk premium could be introduced. Note that the strength of the financial friction can be controlled by the parameter $\kappa$. Moreover, our specification ensures stationarity of the equilibrium dynamics and is based on Schmitt-Grohé and Uribe (2003) with two modifications. First, it takes into account financial amplifier effects of exchange rate depreciations and, second, it prevents that the risk premium can turn negative during the equilibrium adjustment. ${ }^{11}$ Note that we assume that the SOE is hit by the international financial shock in the form of an unexpected, adverse shock to $R P_{t}$.

The firm's optimization problem is to maximize the expected discounted sum of future profits by the choice of $L_{T t}, L_{N t}, K_{T t}, K_{N t}, I M_{t}, B L_{t}, S F_{t}$, and $F L_{t}$. Assuming that the firm is surprised by the financial shock, it solves the following optimization problem based on the information set of period $t-1$ :

$$
\max _{L_{T t}, L_{N t}, K_{T t}, K_{N t}, I M_{t}, B L_{t}, S F_{t} F L_{t}} E_{t-1} \sum_{j=0}^{\infty} \rho_{t, t+j} \pi_{t+j}^{F},
$$

\footnotetext{
${ }^{11}$ The foreign interest rate with a debt-elastic risk premium as in Schmitt-Grohé and Uribe (2003) that incorporates an exchange rate would be: $R_{F t}=(1+r)+\kappa\left(\exp \left(e_{t} F L_{t}-\bar{e} \overline{F L}\right)-1\right)$. This specification, however, does not restrict the lower bound of the gross foreign interest rate to be larger than 1 for $\kappa>r$.
} 
where

$$
\begin{aligned}
\pi_{t}^{F}= & P_{T t} Y_{T t}+P_{N t} Y_{N t}-W_{t} L_{T t}-W_{t} L_{N t}-e_{t} p_{I M t}^{*} I M_{t} \\
& -P_{T t} I_{T t}-P_{T t} A C\left(K_{T t}, K_{T t-1}\right)-P_{N t} I_{N t} \\
& -P_{N t} A C\left(K_{N t}, K_{N t-1}\right)+B L_{t}-R_{B t} B L_{t} \\
& +e_{t} S F_{t}-e_{t} R_{S t} S F_{t}+e_{t} F L_{t}-e_{t} R_{F t-1} F L_{t-1},
\end{aligned}
$$

subject to the working capital constraints (11) and (12). We assume that goods and labor markets are perfectly competitive, which implies that the firm acts as a price taker.

The optimality conditions with respect to labor in the production of tradable and non-tradable goods imply that expected effective marginal costs of labor are equal to their expected marginal products:

$$
\begin{aligned}
& E_{t-1} R_{B t} W_{t}=\left(1-\alpha_{T}\right)(1-\nu) E_{t-1} \frac{P_{T t} Y_{T t}}{L_{T t}}, \\
& E_{t-1} R_{B t} W_{t}=\left(1-\alpha_{N}\right) E_{t-1} \frac{P_{N t} Y_{N t}}{L_{N t}} .
\end{aligned}
$$

The intertemporal optimality condition with respect to capital in the production of both types of goods equates the expected costs and expected benefits of an additional unit of capital:

$$
E_{t-1}\left(1+\gamma \frac{I_{i t}}{K_{i t-1}}\right)=E_{t-1} \rho_{t, t+1}\left(\alpha_{i} \frac{Y_{i t+1}}{K_{i t}}+(1-\delta)-\gamma \frac{I_{i t+1}}{K_{i t}}\left[\frac{1}{2} \frac{I_{i t+1}}{K_{i t}}-\frac{K_{i t+1}}{K_{i t}}\right]\right),
$$

for $i=T, N$. Expected benefits on the right side are equal to the expected marginal product of an additional unit of capital, its resale value after capital depreciation, and associated savings on future capital adjustment costs. The costs in the current period are given by the unit of investment and associated capital adjustment costs.

The optimality condition with respect to imported materials implies that expected effective marginal costs are equal to the expected marginal product:

$$
E_{t-1} e_{t} R_{S t} p_{I M t}^{*}=\left(1-\alpha_{T}\right) \nu E_{t-1} \frac{P_{T t} Y_{T t}}{I M_{t}} .
$$

The intertemporal optimality condition with respect to external long-term credits equates expected benefits and expected costs of an additional unit of long-term foreign credits:

$$
\begin{aligned}
E_{t-1} e_{t} & =E_{t-1} \rho_{t, t+1} e_{t+1}\left(R_{F t}+\frac{\partial R_{F t}}{\partial F L_{t}} F L_{t}\right), \\
\frac{\partial R_{F t}}{\partial F L_{t}} & =\kappa \exp \left(e_{t} F L_{t}-\bar{e} \overline{F L}\right) e_{t} .
\end{aligned}
$$

Expected costs on the right side are equal to the sum of the repayment including interests of an additional unit of foreign credits and its effect on the risk premium.

Since firm profits are distributed to the household at the end of the period, the firm's discount factor is equal to the subjective discount factor of the household:

$$
\rho_{t, t+j}=\beta^{j} \frac{P_{t}}{P_{t+j}} \frac{U_{C_{t+j}}}{U_{C_{t}}} .
$$


Using the expression for the firm's discount factor and combining the household's and firm's intertemporal optimality conditions (6) and (16), we obtain the model's uncovered interest parity (UIP) condition:

$$
E_{t-1} R_{D t}=E_{t-1} \frac{e_{t+1}}{e_{t}}\left(R_{F t}+\frac{\partial R_{F t}}{\partial F L_{t}} F L_{t}\right) .
$$

This condition differs from the usual UIP condition in two aspects: it includes a risk premium term (the second term on the right side) and it holds only in expectations conditioned on information at the end of period $t-1$. This is consistent with Lewis (1995) who finds empirical evidence for the existence of predicted interest rate differentials between home and foreign bonds which can be explained by differences in country risks. Moreover, realized and predicted interest rate differentials can deviate due to expectation errors. In our model, the actual and predicted interest rate differentials coincide as long as there are no unexpected shocks in periods $t$ and $t+1$. If an unexpected shock occurs, the model's UIP condition deviates from the usual UIP condition in the initial period. The risk premium term stems from the fact that the interest rate on external long-term credits incorporates the debt-elastic risk premium. Note that with a positive level of foreign long-term debt, the domestic interest rate exceeds the foreign interest rate in the deterministic steady state and is given by:

$$
\bar{R}_{D}=\bar{R}_{F}+\kappa \bar{e} \overline{F L} .
$$

The associated level of foreign debt in steady state is then equal to $\bar{e} \overline{F L}=\frac{1 / \beta-(1+r)}{\kappa}-1$.

\subsection{Financial Intermediary}

The financial intermediary receives deposits $D_{t}$ at the beginning of each period, and repays $R_{D t} D_{t}$ at the end of each period. Moreover, the financial intermediary lends at the beginning of the period bank loans $B L_{t}$ to the firm, and receives $R_{B t} B L_{t}$ at the end of the same period. It is assumed that the financial intermediary has a second source of funds given by the change in domestic liquidity, $M_{t}-M_{t-1}$, which is controlled by the monetary authority. Note that the different monetary policy rules are described in Section 4. The financial intermediary solves the following problem:

$$
\max _{D_{t}, B L_{t}}=E_{t} \sum_{j=0}^{\infty} \rho_{t, t+j} \pi_{t+j}^{B},
$$

s.t.

$$
\begin{aligned}
\pi_{t}^{B} & =M_{t}-M_{t-1}+D_{t}-R_{D t} D_{t}-B L_{t}+R_{B t} B L_{t}, \\
B L_{t} & =D_{t}+M_{t}-M_{t-1},
\end{aligned}
$$

where (19) represents the bank's balance sheet identity that requires that assets (bank loans) are equal to liabilities (deposits and cash).

In equilibrium, the intermediation margin between bank loans and deposits is zero:

$$
R_{B t}-R_{D t}=0 .
$$

\subsection{Rest of the World}

The rest of the world supplies imports which are employed in the production of tradable goods. We assume that imports are producer-currency priced and that the supply is increasing in the price of imports $p_{I M t}^{*}$ :

$$
I M_{t}=Z_{I M}\left(p_{I M t}^{*}\right)^{\phi_{I M}}, Z_{I M}>0, \phi_{I M}>0,
$$


where $Z_{I M}$ is a positive scaling parameter and $\phi_{I M}$ the price elasticity of supply.

Furthermore, the rest of the world imports tradable goods produced in the SOE. We assume that exports of the SOE are also producer-currency priced and that export demand is decreasing in the price of tradable goods:

$$
C_{t}^{*}=Z_{T}\left(\frac{1}{e_{t}} p_{T t}\right)^{-\phi_{T}}, Z_{T}>0, \phi_{T}>0
$$

where $Z_{T}$, analogously, is a positive scaling parameter and $-\phi_{T}$ the price elasticity of the foreign demand for tradable goods. ${ }^{12}$

\subsection{Market Clearing Conditions}

The market clearing condition for non-tradable goods is given by:

$$
Y_{N t}=C_{N t}+I_{N t}+A C_{N t},
$$

and that for tradable goods by:

$$
Y_{T t}=C_{T t}+I_{T t}+A C_{T t}+C_{t}^{*} .
$$

These two conditions equate production and absorption.

The market clearing condition for labor is:

$$
L_{T t}+L_{N t}=L_{t} .
$$

Combining the household's and firm's cash constraints with the financial intermediary's balance sheet identity, the money market clearing condition corresponds to:

$$
M_{t} \geq P_{t} C_{t} .
$$

This condition requires that actual cash balances equal desired cash balances.

The consolidated budget constraint of the whole economy results from combining the household's budget constraint with those of the firm and the financial intermediary:

$$
\begin{array}{r}
\left(P_{T t} Y_{T t}-P_{T t} C_{T t}-P_{T t} I_{T t}-P_{T t} A C_{T t}\right)+\left(P_{N t} Y_{N t}-P_{N t} C_{N t}\right. \\
\left.-P_{N t} I_{N t}-P_{N t} A C_{N t}\right)+\left(W_{t} L_{t}-W_{t} L_{T t}-W_{t} L_{N t}\right) \\
-e_{t} p_{I M t}^{*} I M_{t}-e_{t}\left(R_{S t}-1\right) S F_{t}-e_{t}\left(R_{F t-1}-1\right) F L_{t-1}=-e_{t}\left(F L_{t}-F L_{t-1}\right) .
\end{array}
$$

Using the market clearing conditions for goods and labor, the consolidated budget constraint reduces to:

$$
P_{T t} C_{T t}^{*}-e_{t} p_{I M t}^{*} I M_{t}-e_{t}\left(R_{S t}-1\right) S F_{t}-e_{t}\left(R_{F t-1}-1\right) F L_{t-1}=-e_{t}\left(F L_{t}-F L_{t-1}\right) .
$$

The economy's trade balance is given by:

$$
T B_{t}=\underbrace{P_{T t} C_{T t}^{*}}_{\text {Exports }}-\underbrace{e_{t} p_{I M t}^{*} I M_{t}}_{\text {Imports }} .
$$

\footnotetext{
${ }^{12}$ The assumption of producer-currency pricing implies that the firm sells tradable goods for the same price on the domestic and foreign market, and that foreign demand increases with an exchange rate depreciation depending on the demand elasticity.
} 
Using the definition of the trade balance, the consolidated budget constraint can be expressed as:

$$
\underbrace{T B_{t}-e_{t}\left(R_{S t}-1\right) S F_{t}-e_{t}\left(R_{F t-1}-1\right) F L_{t-1}}_{\text {Current Account }}=\underbrace{-e_{t}\left(F L_{t}-F L_{t-1}\right)}_{- \text {Capital Account }} \text {. }
$$

This condition represents the economy's balance of payments condition, which requires that the current account (sum of the trade balance and net foreign interest payments) is equal to the negative of the capital account (change in net foreign assets).

\subsection{Equilibrium}

A rational expectations equilibrium of the whole economy is a set of processes for $\left\{C_{t}, C_{T t}, C_{N t}\right.$, $L_{T t}, L_{N t}, L_{t}, I M_{t}, K_{T t}, K_{N t}, I_{T t}, I_{N t}, Y_{T t}, Y_{N t}, \rho_{t, t+1}, P_{T t}, P_{N t}, P_{t}, p_{I M t}^{*}, W_{t}, C_{t}^{*}, D_{t}, B L_{t}, S F_{t}, F L_{t}, R_{D t}$, $\left.R_{B t}, R_{S t}, R_{F t}\right\}_{t=0}^{\infty}$, having the following properties: (1) for each time period and given prices, the quantities solve the optimization problems of the household, firm, and the financial intermediary, and (2) all markets clear. We solve the model by linearizing the equilibrium conditions around the deterministic steady state and solve numerically the linearized system.

\subsection{Estimation}

In this section, theoretical response functions are matched with their empirical counterparts as a function of the structural model parameters. While the first set of parameters is fixed to determine the aggregate economic and financial structure of the model economy in the steady state, the parameters of the second group are estimated by minimizing the distance between theoretical and empirical impulse responses.

The structural parameters of the first group determine the economy's long-run characteristics. These parameters are either provided by averages over the LA- 5 economies or in line with the related literature. The parameters $\left\{n, \alpha_{T}, \nu, \alpha_{N}, \delta\right\}$ determine the relative size of the tradable goods sector, the shares of capital, imports, and labor in the production, and the capital depreciation rate. Table 3 shows the parameter values. Our parameter assumptions imply that tradable production makes up $38 \%$ of total production, the tradable sector employs more capital than the non-tradable sector, and that imports make up $7 \%$ of production costs. ${ }^{13}$ The implied wage costs are $54 \%$ of total production costs. The intertemporal elasticity of substitution of consumption is set to $\sigma=1.001$ and that of labor to 2 , which is implied by imposing $\mu=1.455$ (Mendoza, 1991; Uribe and Yue, 2006). The risk-free foreign interest rate is set to $4 \%$ (p.a.) and the stock of external corporate debt to $20 \%$ of annual GDP. ${ }^{14}$ The sensitivity parameter $\kappa$ in the risk premium is set to 0.04 . Given these assumptions, the steady-state relation $\bar{e} \overline{F L}=\frac{1 / \beta-(1+r)}{\kappa}-1$ implies that the economy's time preference parameter $\beta$ has to be fixed to 0.92 . This makes the economy more impatient and implies that the SOE is a net borrower on international capital markets. The model's balance of payments condition then leads to a trade balance to GDP ratio of $4 \%$ in the steady state. For estimation, we abstract from monetary policy and assume that domestic liquidity remains constant $\Delta M_{t}=0$.

The second group of parameters consists of the remaining structural and stochastic parameters that are to be estimated. We restrict these parameters to intervals that are in line with the empirical evidence. Export and import elasticities are restricted to the interval $\phi_{I M}=\phi_{T}=[0.4,1.5]$, capital adjustment cost parameters to $\gamma_{T}=\gamma_{N}=[0,20]$, the elasticity of substitution between tradable and

\footnotetext{
${ }^{13}$ See Arellano and Mendoza (2003), Christiano et al. (2004) and Kehoe and Ruhl (2009).

${ }^{14}$ In Section 5, we analyze country dynamics for varying levels of leverage.
} 
non-tradable goods to $\lambda=[0.1,0.5]$, and the wealth parameter to $\gamma=[0,0.5] .{ }^{15}$ And finally, we have to estimate the persistence and size of the exogenous financial shock process in (13), which sets in motion the economy's initial deviation from steady state and the subsequent adjustment process. The autoregressive component we restrict to the interval $\rho_{R P}=[0.5,0.9]$ to ensure that the shock process is stationary and the size of the initial shock to $\sigma_{R P}=[0.1,5 \%]$ (p.q.), where the upper bound is determined by the magnitude of the country risk shock used in the impulse response analysis in Section 2.

Empirical and theoretical IRFs are estimated by minimizing a weighted distance between the empirical IRFs estimated in Section 2, $I R^{e}$, and the theoretical IRFs, $I R^{t}{ }^{16}$ Five years of impulse responses are matched by minimizing the following distance:

$$
\begin{gathered}
\min _{\xi}\left[I R^{e}-I R^{t}(\xi)\right]^{\prime} W\left[I R^{e}-I R^{t}(\xi)\right], \\
\xi=\left(\phi_{I M}, \phi_{T}, \gamma_{T}, \gamma_{N}, \lambda, \gamma, \rho_{R P}, \sigma_{R P}\right)
\end{gathered}
$$

subject to $\xi \leq \xi \leq \bar{\xi}$. The weighting matrix $W$ is calculated by the inverse of the covariance matrix of the empirical IRFs, determined in the bootstrap replications in Section 2.

Table 3 shows starting values, interval bands and the resulting parameters. All estimated parameters lie inside their interval bands, except for the wealth parameter which converges to $\gamma=0$. This implies that changes in wealth do not affect labor supply, consistent with the findings of Greenwood et al. (1988). Figure 3 highlights that most of the points belonging to the theoretical IRFs lie inside the bootstrapped confidence intervals. The results also suggest that an initial exogenous shock to the risk premium on foreign long-term credits of $1.5 \%$ is most suitable in explaining the empirical adjustment of the Latin American economies in response to a country risk shock of 5\%, see Section 2. Although only eight parameters are estimated to match 100 points of impulse responses, the theoretical model reproduces the empirical evidence remarkably good: output, investments and domestic credits drop, while the trade balance improves. The initial response of investments is slightly overestimated, while output and domestic credits do not react as much as in reality. Over time theoretical and empirical IRFs get closer.

Figure 4 shows the theoretical responses of other important model variables. In response to the exogenous financial shock in the initial period of $1.5 \%$ (p.q.), the interest rate on external debt, $R_{F t}$, increases to $2.5 \%$ (p.q.) in the next period driven by the financial amplification. The associated currency depreciation amounts to $40 \%$ and external long-term credits decrease by $-1.2 \% .{ }^{17}$ The trade balance improves, as a result from a reduction in imported materials (-12\%) and an increase in exported goods $(30 \%)$. The capital stocks in the tradable and non-tradable goods sector fall by $-4 \%$ and $-3 \%$, respectively, and labor is shifted from the non-tradable (-8\%) to the tradable goods sector $(10 \%)$. Overall the financial shock is associated with a decrease in total economic activity of about $-2 \%$. The economic slowdown is explained by an important contraction in the non-tradable goods sector (-6\%) that is partly offset by an expansion in the tradable goods sector (3\%). Total consumption drops by $-5.5 \%$ with a higher decrease in the consumption of tradable goods $(-6 \%)$.

\footnotetext{
${ }^{15}$ See Goldstein and Khan (1985), Bahmani-Oskooee and Kara (2005), Arellano and Mendoza (2003) and Christiano et al. (2004).

${ }^{16}$ The theoretical counterparts of the empirical variables are log-deviations from the steady state of real GDP, which is defined as the sum of the value added in the tradable and non-tradable sectors less the cost of imported materials deflated by the overall price level, $\left(P_{T} Y_{T}+P_{N} Y_{N}-R_{S} e p^{\star I M} I M\right) / P$, real investment, $\left(P_{T} I_{T}+P_{N} I_{N}\right) / P$, real domestic bank loans, $B L / P$, the trade balance over nominal GDP, $T B / P Y$, and the risk premium of foreign long-term credits $R_{F t}-(1+r)$.

${ }^{17}$ All variables, except interest rates, are in percentage deviations from steady state.
} 


\subsection{The qualitative adjustment}

In the following, we discuss the propagation of the financial shock qualitatively, based on the theoretical responses of the estimated model. The initial shock to the interest rate of external credits implies that the firm faces an unexpected increase in financing costs. The assumption that the household's deposit and firm's production and financing decisions are made prior to the shock implies that the other variables do not react in the initial period. The domestic interest rate remains constant, because both the household's deposit decision and the firm's demand for domestic bank loans are predetermined, while domestic liquidity is held constant. Moreover, because the model's UIP condition holds in expectations, see (18), there is no predicted interest rate differential and no currency depreciation. Consequently, only the foreign interest rate changes in the initial period, while the other prices and quantities are not affected.

In the next period, the firm reduces external borrowing. Given that the domestic interest rate rises by less than the foreign interest rate, the UIP condition implies a currency depreciation that is followed by an expected appreciation. The currency depreciation translates for the firm into an adverse balance sheet effect, as the value of the stock of external debt increases in domestic currency. For a given level of external debt, the depreciation causes an increase in the risk premium and amplifies the reduction in foreign borrowing. The firm faces opposite effects on operating profits in the form of higher costs for imported materials and increased export earnings. In combination with the increased costs of investment implied by rising interest rates, this translates into a higher labor demand in the tradable good sector and the firm reallocates resources from the non-tradable to the tradable goods sector. For the household, the financial shock translates into a negative wealth effect, because dividend and wage payments decrease. In response, the household reduces consumption. Overall the financial shock, amplified by currency depreciation, adverse balance sheet and risk premium effects results is in persistent drops in economic activity and domestic absorption.

\section{Optimal Monetary Policy}

In this section we analyze what would be the monetary authority's optimal response to an adverse international financial shock, assuming that the central bank is surprised by the shock in the initial period as is the rest of the economy. In order to conduct a monetary policy evaluation, we rely on a quadratic loss function that penalizes deviations of expected inflation and real GDP $\left(Y_{t}\right)$ from their steady-state values. Furthermore we characterize monetary policy as an implementable, simple interest rate feedback rule, as in Schmitt-Grohé and Uribe (2007), that responds to various combinations of inflation, output and the nominal exchange rate. The monetary authority's objective is to minimize a quadratic loss function of the form: ${ }^{18}$

$$
\min _{a} E_{t-1} \operatorname{Loss}_{t}=\lambda_{P}\left(E_{t-1} \widetilde{P}_{t}-\widetilde{P}_{t-1}\right)^{2}+\lambda_{Y}\left(E_{t-1} \widetilde{Y}_{t}\right)^{2},
$$

where variables with $\sim$ indicate linear approximations of the deviations from the steady state and $a$ denotes a vector of the coefficients in the monetary policy rule, as discussed below. The minimization problem is subject to the system of equations that describe the underlying model, including the monetary policy rule.

\footnotetext{
${ }^{18}$ Per model assumptions, inflation is zero in the steady state. Furthermore, we assume that the weights in the loss function are set equally, i.e. $\lambda_{P}=\lambda_{Y}=1$.
} 
We consider two alternative interest-rate feedback rules. The first rule represents a standard inflation targeting rule, adjusted for the timing in the model:

$$
\widetilde{R C} t=a_{1}\left(E_{t-1} \widetilde{P}_{t}-\widetilde{P}_{t-1}\right)+a_{2} E_{t-1} \widetilde{Y}_{t} .
$$

Under this monetary policy regime, minimizing the loss function implies that the monetary authority establishes a complete inflation targeting (IT) regime with a negligible response to output. ${ }^{19}$ Figure 5 shows the theoretical impulse response functions for the IT rule, along with the baseline scenario of a constant money supply. Following an exogenous increase in the risk premium, the domestic currency depreciates due to the UIP condition and leads to inflation on the back of rising import prices. The monetary authority successfully combats inflation by raising the domestic interest rate. This in turn reduces the differential between the foreign and domestic interest rate, leading to a smaller exchange rate depreciation than in the baseline scenario. The lower currency depreciation mitigates adverse balance sheet and risk premium effects and alleviates the decline in demand for foreign credits. As a consequence, the drops investment, employment, real GDP and consumption are less pronounced and the overall price level is stabilized.

Alternatively, we assume that the monetary authority partly targets the expected exchange rate, in addition to inflation and output:

$$
\widetilde{R C}{ }_{t}=a_{0} E_{t-1} \widetilde{e}_{t}+a_{1}\left(E_{t-1} \widetilde{P}_{t}-\widetilde{P}_{t-1}\right)+a_{2} E_{t-1} \widetilde{Y}_{t}
$$

Under this policy rule, the exchange rate targeting rule (ERT), the monetary authority puts some weight on exchange rate stability, in contrast to the pure IT rule. Minimizing the loss function implies that the monetary authority controls primarily inflation — but to a much lesser extent than under the IT rule - and it puts an additional positive weight on exchange rate stabilization and a minimal weight on stabilizing GDP. ${ }^{20}$

Figure 5 shows the theoretical impulse responses for the ERT rule, together with those for the IT rule and the baseline scenario. In absence of a monetary policy response, the initial adverse effects of the exogenous increase in the risk premium are amplified by the exchange rate depreciation and its effect on the debt-elastic part of the risk premium. To minimize this amplifying effect, the monetary authority chooses to stabilize the exchange rate. However, it will take a prolonged period to bring the exchange rate back to its initial level. Rational agents have full information about the monetary policy pursued in each period after the shock and know therefore that the domestic interest rate will rise in the future. Expecting higher interest rates in the future, households reduce their demand today due to substitution and wealth effects. This in turn leads to a deflation and a lower interest rate today. Because of a lower exchange rate depreciation and therefore lower risk premium under the ERT, as compared to the baseline scenario and the IT rule, the demand for foreign credits recovers quickly and strongly, leading to a lower initial reduction in investment, labor, real GDP and consumption. The monetary authority manages to keep the exchange rate in check after ten quarters. Although the initial output contraction is substantially smaller compared to the baseline scenario and the IT rule, the recovery is still long-lasting.

Comparing the loss values of the objective function under these two monetary policy rules, we evaluate the ERT rule as the better rule. ${ }^{21}$ Combating the exchange rate depreciation helps the monetary authority to limit the domestic amplification of an exogenous risk premium shock, reducing initial

\footnotetext{
${ }^{19}$ Without an upper bound on the inflation coefficient, the optimal policy rule involves a very large inflation coefficient $\left(a_{1}=1200\right)$ and an almost zero output coefficient $\left(a_{2}=0.03\right)$, where values for $a_{1}$ above 60 do not lead to any significant decreases in the loss function.

${ }^{20}$ The optimal policy rule involves the following coefficients: $a_{0}=0.6, a_{1}=7$ and $a_{2}=0.02$.

${ }^{21}$ Under the IT rule the optimized loss function value is 0.018 , while under the ERT rule it reaches 0.011 .
} 
negative responses of consumption, investment, employment and output. However, due to higher future interest rates, the recovery is still protracted, but not longer than under the IT rule.

\section{The Role of Leverage}

In this section we compare the theoretical impulse responses for different levels of external leverage in the baseline scenario of a constant money supply. For this purpose we vary the time preference parameter $\beta$, which determines the economy's impatience and therefore its willingness to borrow. Figure 6 shows the economy's response to a financial shock of an initially equivalent magnitude for external debt to GDP ratios of $25 \%$ and $10 \%$ in the steady state. In the high-debt economy, the financial amplification leads to a rise in the foreign interest rate of $3.5 \%$ (p.q.), as opposed to $2 \%$ in the medium-debt economy. The recession in the highly leveraged economy is more pronounced and persistent. For instance, the exchange rate depreciates by $60 \%$ and output drops by $3 \%$ in the high-debt economy, compared to a depreciation of $20 \%$ and output drop of $1 \%$ in the medium-debt economy. Similar, while the ensuing inflation in the medium-debt economy is rather small, the highdebt economy suffers a prolonged period of increasing prices.

The intuition for these results is the following. Given the same magnitude of the initial exogenous financial shock, interest payments of the high-debt economy increase by more compared to those of the medium-debt economy. There is also an important balance sheet effect involved implied by the higher depreciation of the exchange rate. In combination, the two effects result in a higher reduction of the economy's wealth. In order to compensate the adverse wealth effect, the high-debt economy finds it optimal to reduce external borrowing by more than the medium-debt economy, which is associated with a stronger improvement in the trade balance on the back of important drops in domestic production and investment. The feedback mechanism between currency depreciation, adverse balance sheet and risk premium effects sets in motion a vicious circle of financial amplification in the high-debt economy.

\section{Concluding remarks}

The present paper investigated how an emerging market economy is affected when it suddenly faces a high risk premium on international financial markets. We studied this question empirically for five Latin American economies within a structural panel VAR model and analyzed theoretically the financial shock propagation to the real economy, using a dynamic general equilibrium model of a small open economy. In our theoretical framework, the financial shock hits initially the risk premium of firms' foreign-currency debt and is amplified by a feedback mechanism between currency depreciation, adverse balance sheet and risk premium effects.

In our model the economy responds to the financial shock by reducing external borrowing. During the transition, the debt-elastic risk premium limits the economy's ability to smooth out the adverse effects on output and employment. The domestic currency depreciates in response and overshoots. Our framework highlights that initially small shocks can culminate in prolonged recessions. The ultimate response of the economy depend on its structural characteristics, most importantly, the level of foreign-currency debt, importance of export revenues and import dependence.

After estimating the structural parameters, the theoretical model reproduces the empirical impulse responses of GDP, investments, trade balance and domestic credits associated with an adverse shock to the country risk premium remarkably good. Regarding monetary policy implications, we find that an exchange rate targeting rule that strikes a balance between exchange rate and inflation targeting 
allows the monetary authority to stabilize inflation and output more effectively than a pure inflation targeting rule. Combating the exchange rate depreciation helps limiting the domestic amplification of the exogenous financial shock. 


\section{References}

Arellano, C. and Mendoza, E. (2003). Credit Frictions and 'Sudden Stops' in Small Open Economies: An Equilibrium Business Cycle Framework for Emerging Market Crises. In Altug, S., Chadha, J., and Nolan, C., editors, Dynamic Macroeconomic Analysis: Theory and Policy in General Equilibrium. Cambridge University Press.

Arellano, M. and Bover, O. (1995). Another look at the instrumental variable estimation of errorcomponents models. Journal of Econometrics, 68:29-51.

Bahmani-Oskooee, M. and Kara, O. (2005). Income and Price Elasticities of Trade: Some New Estimates. International Trade Journal, 19(2):165-178.

Banco de Mexico (2009). Exchange rate regimes in mexico since 1954. Banco de Mexico, September.

Batten, J. A. and Szilagyi, P. G. (2011). The impact of the global financial crisis on emerging financial markets. Contemporary Studies in Economic and Financial Analysis, 93:3-16.

Berganza, J. C., Chang, R., and Herrero, A. G. (2004). Balance Sheet Effects and the Country Risk Premium: An Empirical Investigation. Review of World Economics, 140(4):592-612.

Bernanke, B. and Gertler, M. (1989). Agency costs, net worth, and business fluctuations. American Economic Review, 79(1):14-31.

Braggion, F., Christiano, L. J., and Roldos, J. (2009). Optimal monetary policy in a sudden stop. Journal of Monetary Economics, 56(4):582-595.

Brei, M. and Charpe, M. (2012). Currency depreciations, financial transfers, and firm heterogeneity. Emerging Markets Review, 13:26-41.

Calvo, G. and Reinhart, C. (2002). Fear of floating. Quarterly Journal of Economics, 117(2):379-408.

Calvo, G. and Talvi, E. (2005). Sudden stop, financial factors and economic collapse in Latin America: Learning from Argentina and Chile. NBER Working Paper Series, No. 11153.

Calvo, G. A., Izquierdo, A., and Talvi, E. (2006). Sudden stops and phoenix miracles in emerging markets. American Economic Review, 96(2):405-410.

Céspedes, L. F., Chang, R., and Velasco, A. (2004). Balance Sheets and Exchange Rate Policy. American Economic Review, 94(4):1183-1193.

Christiano, L. J. (1991). Modeling the Liquidity Effect of a Money Shock. Federal Reserve Bank of Minneapolis, Quarterly Review, 1511:3-34.

Christiano, L. J. and Eichenbaum, M. (1992). Liquidity Effects and the Monetary Transmission Mechanism. American Economic Review, Papers and Proceedings, 82(2):346-353.

Christiano, L. J., Eichenbaum, M., and Evans, C. L. (1997). Sticky price and limited participation models of money: A comparison. European Economic Review, 41:1201-1249.

Christiano, L. J., Eichenbaum, M., and Evans, C. L. (1999). Monetary policy shocks: What have we learned and to what end? Handbook of Macroeconomics, 1A. 
Christiano, L. J., Eichenbaum, M., and Evans, C. L. (2005). Nominal rigidities and the dynamic effects of a shock to monetary policy. Journal of Political Economy, 113(1):1-43.

Christiano, L. J., Gust, C., and Roldos, J. (2004). Monetary policy in a financial crisis. Journal of Economic Theory, 119:64-103.

Christiano, L. J., Motto, R., and Rostagno, M. (2010). Financial factors in economic fluctuations. ECB Working Paper Series No. 1192.

Cook, D. and Devereux, M. B. (2005). Accounting for the East Asian Crisis: A Quantitative Model of Capital Outflows in Small Open Economies. Journal of Money, Credit and Banking, 38(3):721749.

De Gregorio, J. (2013). Resilience in latin america: Lessons from macroeconomic management and financial policies. IMF Working Paper No. 13/259.

Del Negro, M., Eggertsson, G., Ferrero, A., and Kiyotaki, N. (2011). The great escape? a quantitative evaluation of the fed's non-standard policies. Federal Reserve Bank of New York Staff Papers No. 520.

Dornbusch, R., Park, Y. C., and Claessens, S. (2002). Contagion: Understanding how it spreads. The World Bank Research Observer, 2:177-197.

Eichengreen, B., Hausmann, R., and Panizza, U. (2005). The Pain of Original Sin. In Eichengreen, B. and Hausmann, R., editors, Others People's Money: Debt Denomination and Financial Instability in Emerging Market Economies, pages 13-47. The University of Chicago Press, Chicago.

Fisher, I. (1933). The debt-deflation theory of great depressions. Econometrica, 1(4):337-347.

Frenkel, R. and Rapetti, M. (2010). A concise history of exchange rate regimes in Latin America. CEPR, April.

Friedman, M. (1968). The role of monetary policy. American Economic Review, 58:1-17.

Gambacorta, L. and Signoretti, F. M. (2014). Should monetary policy lean against the wind? Journal of Economic Dynamics and Control, 43(C):146-174.

García-Cicco, J., Pancrazi, R., and Uribe, M. (2010). Real Business Cycles in Emerging Countries. American Economic Review, 100(5):2510-2531.

Gavin, W. and Theodorou, A. (2005). A common model approach to macroeconomics: using panel data to reduce sampling error. Journal of Forecasting, 24:203-219.

Gerali, A., Neri, S., Sessa, L., and Signoretti, F. M. (2010). Credit and banking in a dsge model of the euro area. Journal of Money, Credit and Banking, 46(6):44-70.

Gertler, M., Gilchrist, S., and Natalucci, F. M. (2007). External Constraints on Monetary Policy and the Financial Accelerator. Journal of Money, Credit and Banking, 39:295-330.

Gilchrist, S., Yankov, V., and Zakrajsek, E. (2009). Credit market shocks and economic fluctuations: Evidence from corporate bond and stock markets. Journal of Monetary Economics, 56:471-493. 
Goldstein, M. and Khan, M. S. (1985). Income and Price Effects in International Trade. In Jones, R. W. and Kenen, P. B., editors, Handbook of International Economics, volume II, pages 10411105. Elsevier Science Publishers B. V.

Goodhart, C. and Hofmann, B. (2008). House prices, money, credit, and the macroeconomy. Oxford Review of Economic Policy, 24:180-205.

Greenwood, J., Hercowitz, Z., and Huffman, G. W. (1988). Investment, Capacity Utilization, and the Real Business Cycle. American Economic Review, 78(3):402-417.

Hausmann, R., Panizza, U., and Stein, E. (2001). Why do countries float the way they float? Journal of Development Economics, 66(2):387-414.

Jermann, U. and Quadrini, V. (2012). Macroeconomic effects of financial shocks. American Economic Review, 102(1):238-271.

Kehoe, T. J. and Ruhl, K. J. (2009). Sudden Stops, Sectoral Reallocations, and the Real Exchange Rate. Journal of Development Economics, 89(2):235-249.

Kiyotaki, N. and Moore, J. (1997). Credit cycle. The Journal of Political Economy, 105(2):211-248.

Kollmann, R., Enders, Z., and Müller, G. (2011). Global banking and international business cycles. European Economic Review, 55:307-442.

Lewis, K. (1995). Puzzles in International Financial Markets. In Grossman, G. and Rogoff, K., editors, Handbook of International Economics, volume III, pages 1913-1971. Elsevier Science Publishers B. V.

Lown, C. and Morgan, D. (2004). The credit cycle and the business cycle: New findings using the loan officer opinion survey. Journal of Money, Credit and Banking, 38(6):1575-1597.

Mendoza, E. G. (1991). Real Business Cycles in a Small Open Economy. American Economic Review, 81(4):797-818.

Mendoza, E. G. (2006). Lessons from the Debt-Deflation Theory of Sudden Stops. American Economic Review, Papers and Proceedings, 96(2):411-416.

Mendoza, E. G. (2010). Sudden stops, financial crises, and leverage. American Economic Review, 100:1941-1966.

Nickell, S. (1981). Biases in dynamic models with fixed effects. Econometrica, 49:1417-1426.

Roubini, N. and Setser, B. (2004). Bailouts or bail-ins? Responding to financial crises in emerging economies. Peterson Institute for International Economics, Washington, D.C.

Schmitt-Grohé, S. and Uribe, M. (2003). Closing small open economy models. Journal of International Economics, 61:163-185.

Schmitt-Grohé, S. and Uribe, M. (2007). Optimal simple and implementable monetary and fiscal rules. Journal of Monetary Economics, 54(6):1702-1725.

Tornell, A. and Westermann, F. (2002). The Credit Channel in Middle Income Countries. NBER Working Paper No. 9355. 
Uribe, M. and Yue, V. Z. (2006). Country spreads and emerging countries: Who drives whom? Journal of International Economics, 69:6-36. 


\section{Appendix}

Table 1: Summary statistics for the regression variables

\begin{tabular}{lccccc}
\hline \hline \multicolumn{1}{c}{ Variable } & Mean & Std. Dev. & Min. & Max. & Obs. \\
\hline GDP & -0.002 & 0.057 & -0.098 & 0.173 & 198 \\
Investments & -0.006 & 0.165 & -0.504 & 0.569 & 198 \\
Trade balance & 0.001 & 0.040 & -0.103 & 0.164 & 198 \\
Credits & 0.004 & 0.137 & -0.318 & 0.322 & 198 \\
Country spread (p.a.) & 0.064 & 0.052 & 0.009 & 0.363 & 198 \\
\hline \hline
\end{tabular}

${ }^{a}$ The sample includes Brazil (1995/Q1-2007/Q4), Colombia (1994/Q1-2007/Q4), Ecuador (1995/Q2-2002/Q1), Mexico (1994/Q1-2007/Q4) and Peru (1994/Q1-2007/Q4). Where applicable, the variables have been seasonally adjusted. GDP, investments and domestic credits are expressed in real terms and shown as log deviations from a log-linear trend. The trade balance is expressed as a ratio over GDP. The country spread is measured by J.P. Morgan's EMBI+ stripped spread, a composite index of different liquid dollar-denominated debt instruments such as Brady bonds, Eurobonds and traded loans by sovereign entities.

Sources: IMF International Financial Statistics; Datastream. 
Table 2: Estimation results for the structural panel VAR

\begin{tabular}{l|lllll}
\hline Independent & \multicolumn{5}{|c}{ Dependent variables } \\
variables & $y_{t}$ & $i_{t}$ & $t b_{t}$ & $c_{t}$ & $r_{t}$ \\
\hline \hline$y_{t}$ & - & $1.43^{* * *}$ & 0.09 & 0.19 & $-0.29^{* * *}$ \\
$y_{t-1}$ & $0.69^{* * *}$ & $-0.47^{* *}$ & 0.03 & $-0.43^{* *}$ & $0.20^{* * *}$ \\
$y_{t-2}$ & 0.13 & $-0.76^{* * *}$ & $-0.06^{*}$ & -0.09 & 0.08 \\
$i_{t}$ & - & - & $-0.12^{* * *}$ & -0.06 & 0.04 \\
$i_{t-1}$ & $0.07^{*}$ & $0.73^{* * *}$ & $0.09^{* * *}$ & 0.08 & -0.05 \\
$i_{t-2}$ & -0.01 & 0.14 & 0.01 & 0.09 & 0.00 \\
$t b_{t}$ & - & - & - & 0.45 & $0.32^{* *}$ \\
$t b_{t-1}$ & -0.06 & $-0.90^{* *}$ & $1.28^{* * *}$ & -0.57 & -0.35 \\
$t b_{t-2}$ & $0.36^{* *}$ & $0.99^{* *}$ & $-0.41^{* * *}$ & 0.26 & 0.10 \\
$c_{t}$ & - & - & - & - & 0.07 \\
$c_{t-1}$ & 0.02 & -0.03 & -0.01 & $1.01^{* * *}$ & -0.03 \\
$c_{t-2}$ & -0.03 & 0.05 & 0.01 & $-0.12^{* * *}$ & -0.01 \\
$r_{t}$ & - & - & - & - & - \\
$r_{t-1}$ & $-0.16^{* *}$ & $-0.15^{* *}$ & $0.11^{* *}$ & -0.14 & $0.62^{* * *}$ \\
$r_{t-2}$ & 0.04 & 0.08 & $-0.10^{* * *}$ & -0.15 & 0.17 \\
\hline \hline Observations & 198 & 198 & 198 & 198 & 198 \\
AR(2) test & 0.700 & 0.117 & 0.535 & 0.186 & 0.212 \\
Sargan test & 0.011 & 0.808 & 0.914 & 0.899 & 0.791 \\
\hline \hline
\end{tabular}

${ }^{a}$ The sample period goes from 1994/Q1-2007/Q4 and included are Brazil, Colombia, Ecuador, Mexico and Peru. All estimations are based on the Arellano and Bover (1995) system GMM estimator. $y_{t}$ denotes GDP, $i_{t}$ investment, $t b_{t}$ trade balance, $c_{t}$ domestic credits and $r_{t}$ country risk. 'AR(2) test' denotes the Arellano-Bond test for autocorrelation in the residuals of order 2, and 'Sargan test' the Sargan test of overidentifying restrictions: $p$-values are reported. The constant and country-fixed effects are not reported. ${ }^{* * *},{ }^{* *},{ }^{*}$ indicate significance at the $1 \%, 5 \%$, and $10 \%$ levels based on robust standard errors. 
Table 3: Structural parameters

\begin{tabular}{|c|c|c|c|c|}
\hline Parameter & $\begin{array}{l}\text { Starting } \\
\text { Value }\end{array}$ & Interval & $\begin{array}{l}\text { Estimation } \\
\text { Result }\end{array}$ & Description \\
\hline$\beta$ & 0.92 & & & time preference \\
\hline$\mu$ & 1.455 & & & intertemporal EoS of labor \\
\hline$\sigma$ & 1.001 & & & intertemporal EoS of consumption \\
\hline$n$ & 0.3 & & & share of $C_{T}$ in $C$ \\
\hline$\lambda$ & 0.14 & {$[0.1,0.5]$} & 0.12 & EoS between $C_{N}$ and $C_{T}$ \\
\hline$\gamma$ & 0 & {$[0,0.5]$} & 0 & disutility of labor \\
\hline$\alpha_{T}$ & 0.3 & & & capital share in $Y_{T}$ \\
\hline$\alpha_{N}$ & 0.4 & & & capital share in $Y_{N}$ \\
\hline$\delta$ & 0.026 & & & capital depreciation \\
\hline$r$ & 0.01 & & & risk-free interest rate \\
\hline$\kappa$ & 0.04 & & & risk premium parameter \\
\hline$\nu$ & 0.3 & & & share of imports in $Y_{T}$ \\
\hline$\gamma_{T}$ & 0 & {$[0,20]$} & 13.11 & $K_{T}$ adjustment costs \\
\hline$\gamma_{N}$ & 0 & {$[0,20]$} & 11.79 & $K_{N}$ adjustment costs \\
\hline$Z_{I M}$ & 0.1 & & & import supply parameter \\
\hline$Z_{T}$ & 0.1 & & & export demand parameter \\
\hline$\phi_{I M}$ & 0.7 & {$[0.4,1.5]$} & 1.31 & price elasticity of import supply \\
\hline$\phi_{T}$ & 0.8 & {$[0.5,1.5]$} & 1.20 & price elasticity of export demand \\
\hline$\sigma_{R P}$ & 0.03 & {$[0.001,0.05]$} & 0.015 & size of the financial shock in $R P_{t}$ \\
\hline$\rho_{R P}$ & 0.7 & {$[0.5,0.9]$} & 0.88 & persistence of $R P_{t}$ \\
\hline
\end{tabular}

${ }^{a}$ The table summarizes the numerical values of the structural parameters used for the simulation of the DSGE model, as discussed in Section 3.7. 'EoS' denotes elasticity of substitution. A subset of parameters has been estimated by impulse response matching. When the columns 'Interval' and 'Estimation' are empty, this means that the parameters have been fixed. 
Figure 2: Empirical impulse responses to country risk shocks ${ }^{a}$
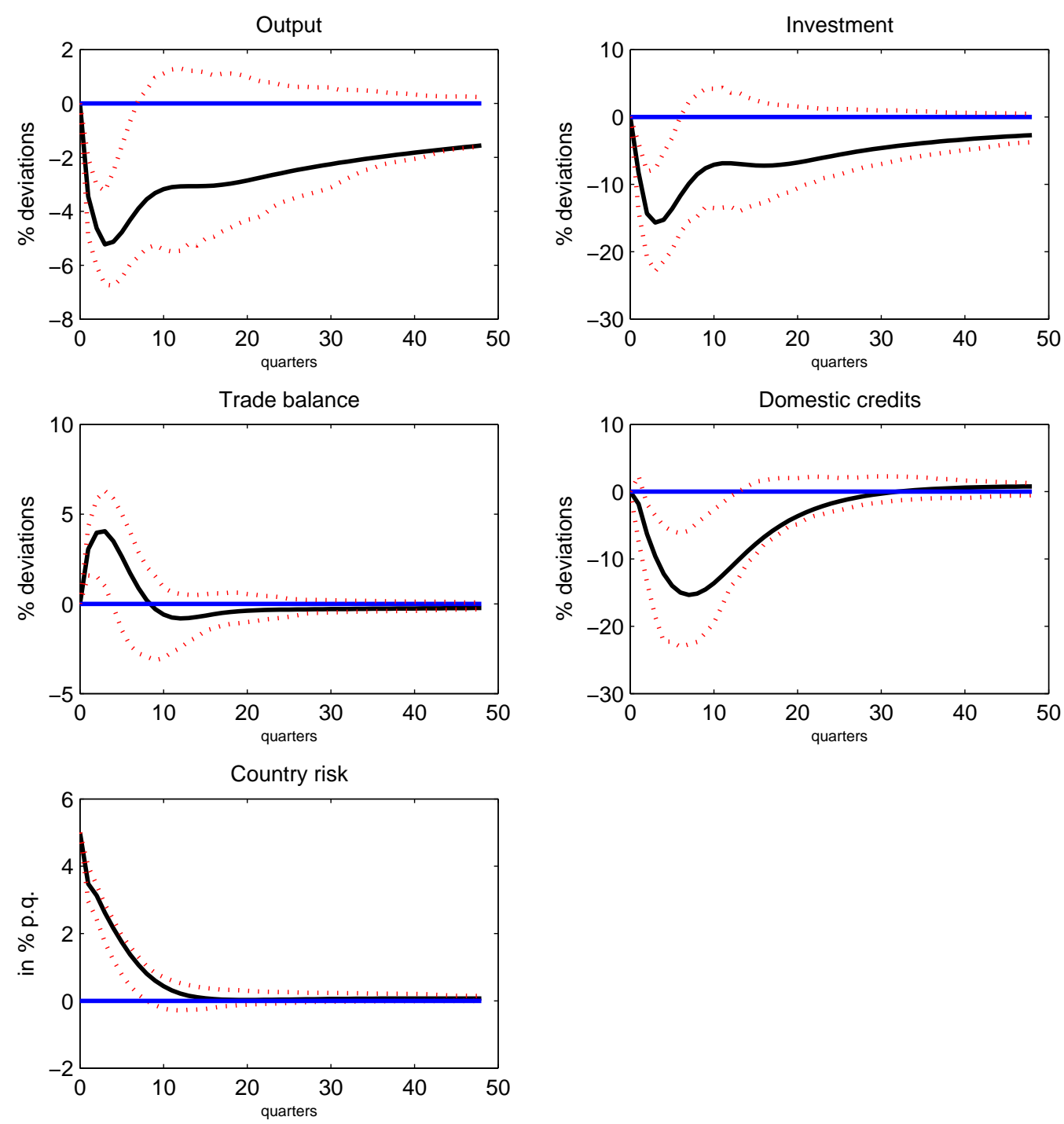

${ }^{a}$ The impulse response functions are based on the regressions shown in Table 2. GDP, investment and domestic credits are shown as percentage deviations from trend, while the trade balance is expressed as a ratio over GDP. The dotted lines indicate the 10 and $90 \%$ bootstrap intervals based on 1000 replications of estimation. In each replication, we generated artificial data using the estimated coefficients and resampled residuals, re-estimating the VAR and IRFs. The bootstrap intervals are the 10 and 90th percentile of the resulting distribution of IRFs. 
Figure 3: Empirical and theoretical impulse responses ${ }^{a}$
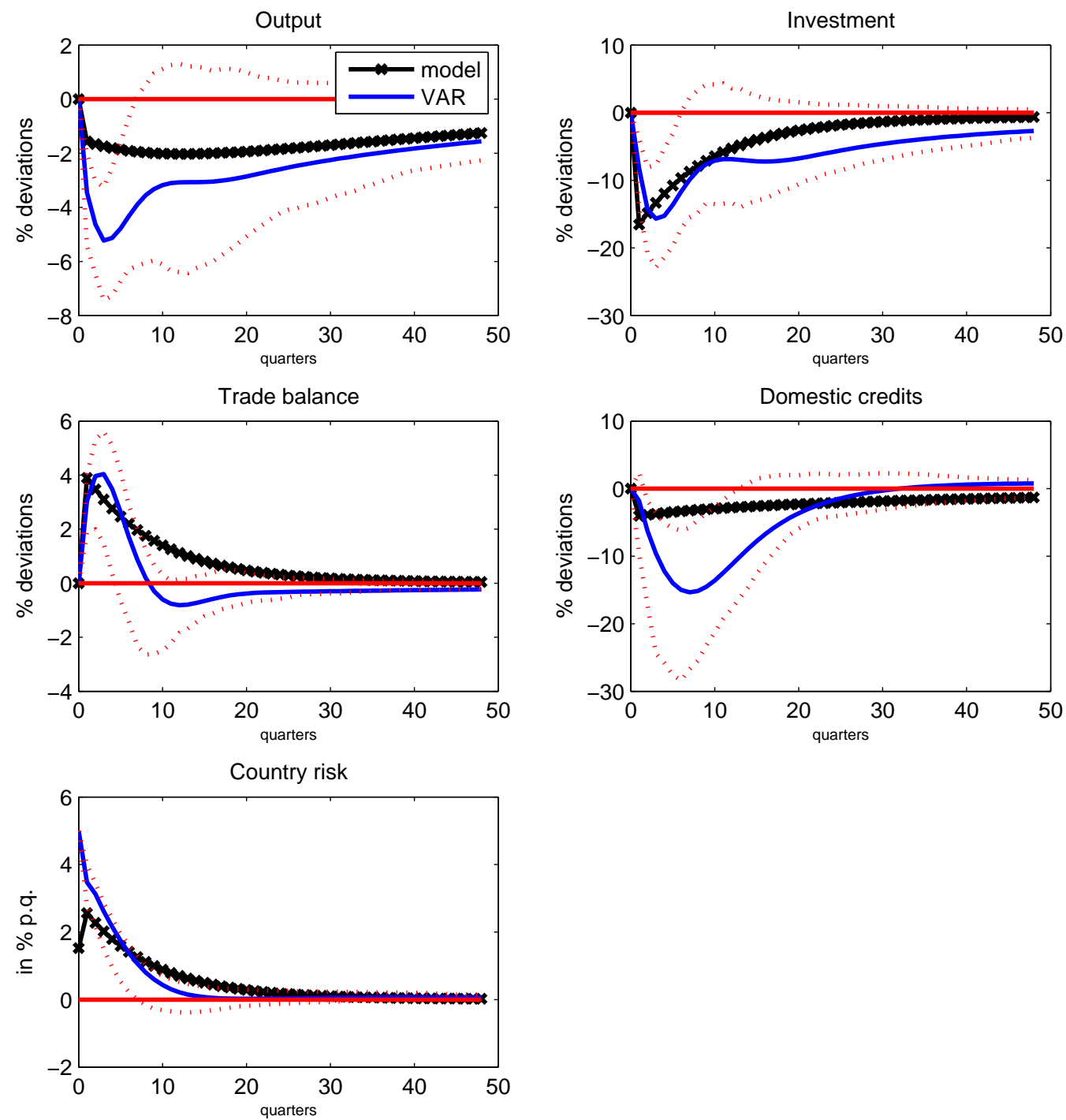

${ }^{a}$ Empirical impulse response functions ('VAR') and bootstrapped confidence intervals are shown, as in Figure 2, along with the theoretical impulse response functions ('model'), see Section 3.7. Figure 4 shows the theoretical impulse responses of other important model variables. 
Figure 4: Theoretical impulse responses ${ }^{a}$
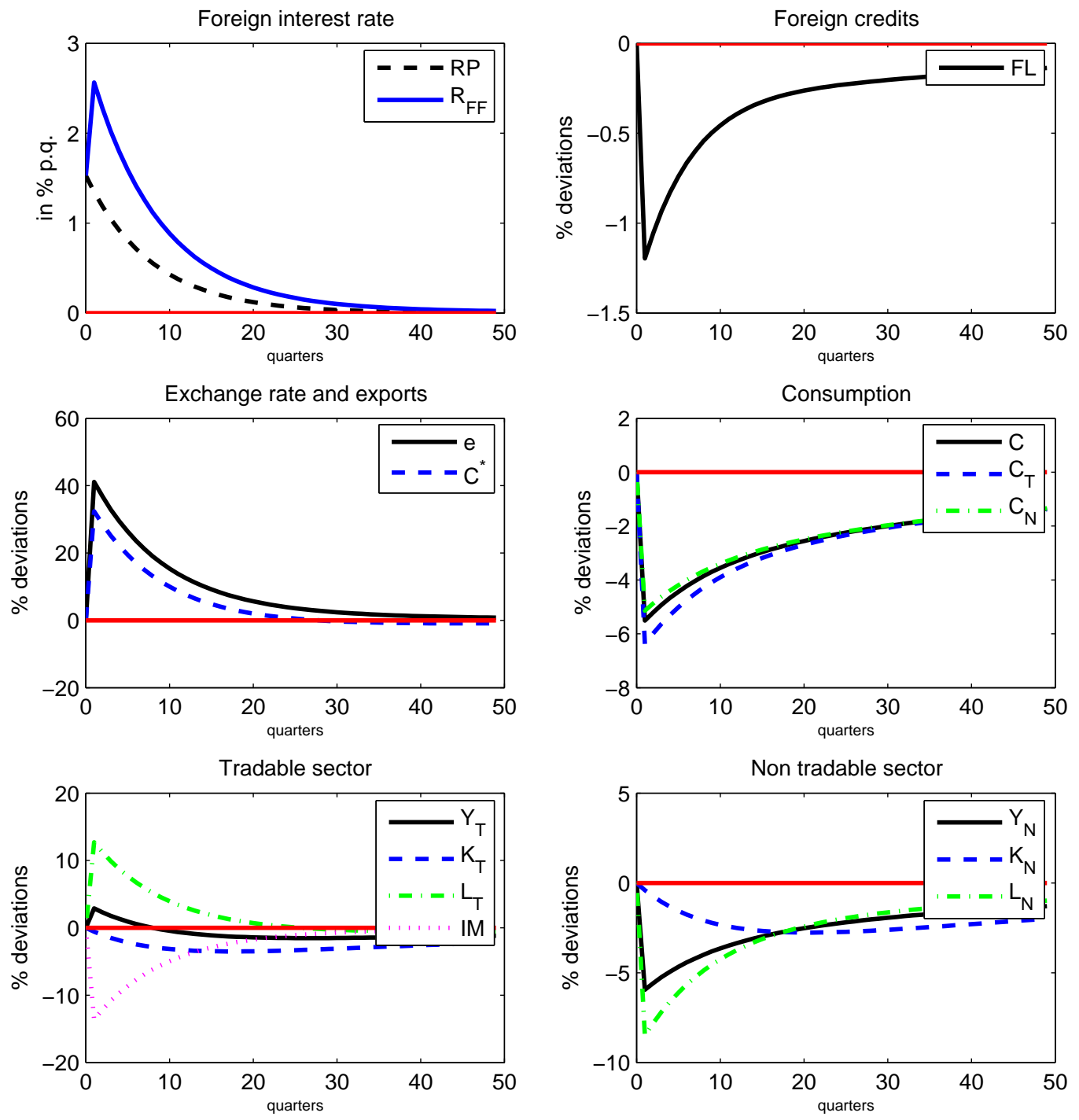

\footnotetext{
${ }^{a}$ The estimation of the theoretical impulse responses are discussed in Section 3.7. The title of each sub-graph indicates the considered variable. $R P$ is the exogenous shock to the risk premium on long-term credits, and $R_{F F}=R_{F t}-(1+r)$ the interest rate on foreign long-term credits, $F L$. The variables $e, C^{*}, C, Y, K, L, I M$ denote the exchange rate, exports, consumption, production, capital, labor and imports, respectively. A subscript ' $T$ ' indicates the tradable goods sector, while a subscript ' $\mathrm{N}$ ' the non-tradable goods sector. Apart from the interest rates, all variables are expressed as percentage deviations from steady state.
} 
Figure 5: Inflation targeting (IT) versus exchange rate targeting (ERT) ${ }^{a}$
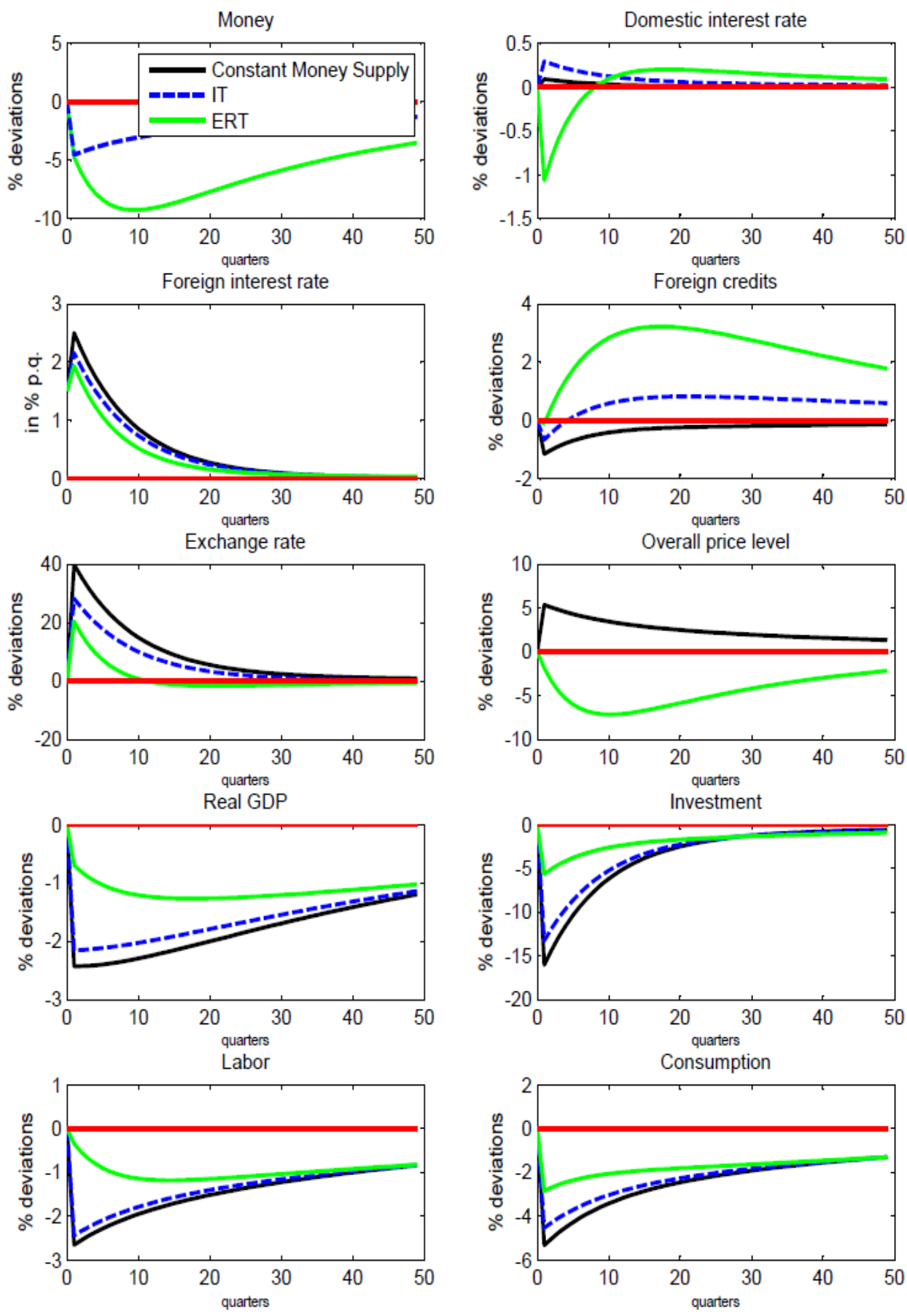

${ }^{a}$ Theoretical response functions are shown for a constant money supply (as in Figures 3 and 4), and two alternative monetary policy rules: inflation targeting (IT) and exchange rate targeting (ERT). See Section 4 for more details. 
Figure 6: Theoretical impulse responses for different levels of external leverage ${ }^{a}$
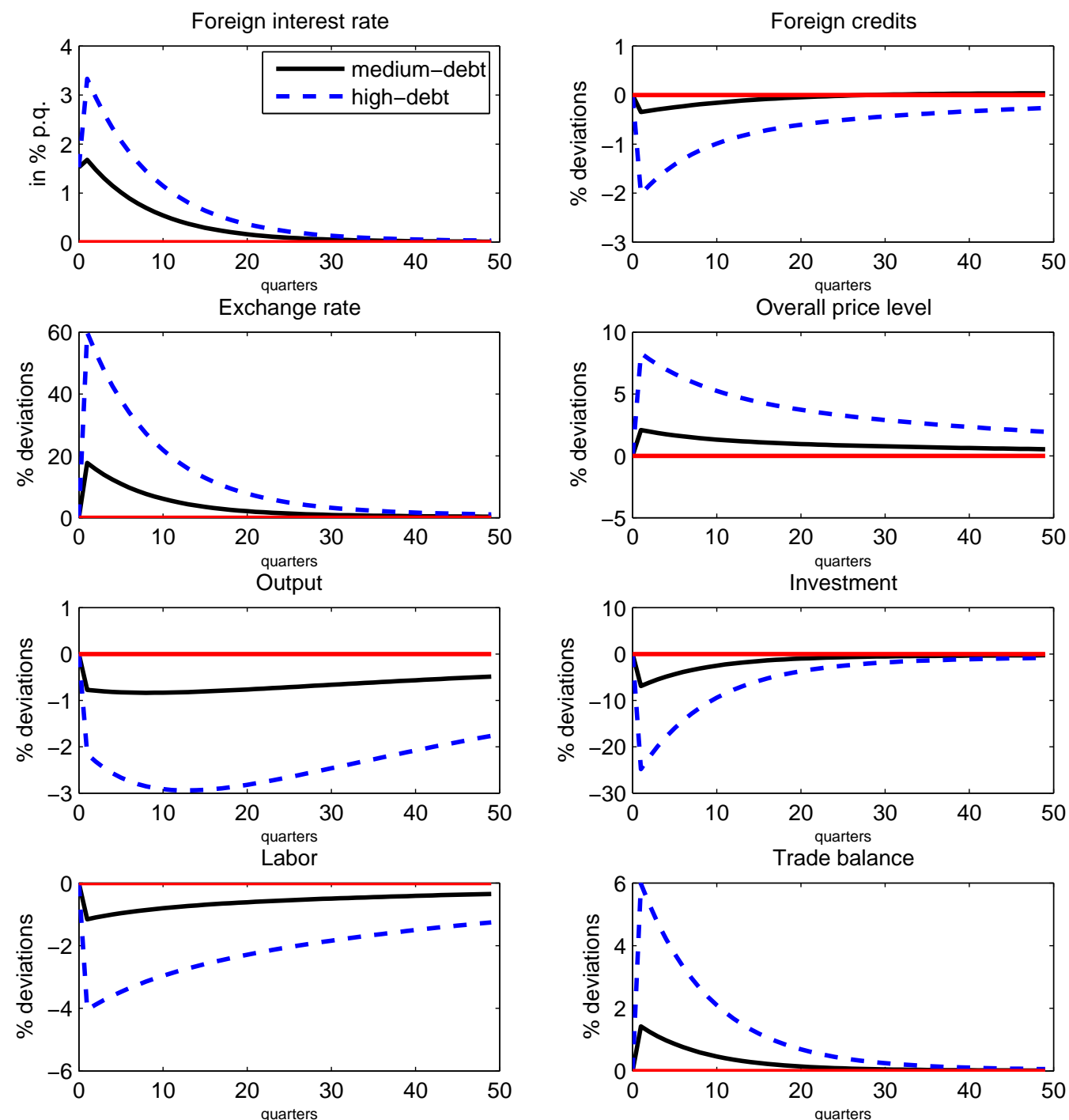

${ }^{a}$ The theoretical response functions are shown for a high-debt and medium-debt economy, with external debt to GDP ratios in the steady state of $25 \%$ and $10 \%$, respectively. See Section 5 for more details. 